\title{
Screening for carcinoma in situ of the contralateral testis in patients with germinal testicular cancer
}

\author{
JØRGEN G BERTHELSEN, NIELS E SKAKKEBÆK, HANS VON DER MAASE, \\ BENT L SØRENSEN, PETER MOGENSEN
}

\begin{abstract}
Two hundred and fifty biopsy specimens from the contralateral testis in patients with unilateral germinal testicular cancer were analysed by light microscopy for carcinoma-in-situ changes. Changes were found in 13 $(5 \cdot 2 \%)$ patients. One-third of patients with an atrophic contralateral testis (volume $\leqslant 12 \mathrm{ml}$ ) and one-fifth of patients with a history of cryptorchidism had changes in the remaining testis. In the present series $85 \%$ of cases with carcinoma-in-situ changes would have been diagnosed if the one-fifth of the patients having an atrophic testis or a history of cryptorchidism or both had been screened.

Since the natural course of carcinoma in situ in the contralateral testis of patients with germinal testicular cancer has not been established, the patients are being re-evaluated frequently. To date two patients with carcinoma in situ have developed a second cancer.
\end{abstract}

\section{Introduction}

Patients with germinal testicular cancer have an increased risk of also developing a cancer in the contralateral testis. ${ }^{1-3}$ The

\footnotetext{
Laboratory of Reproductive Biology and Fertility Clinic, University Department of Obstetrics and Gynaecology, Rigshospitalet, and University Department of Gynaecology and Obstetrics, Herlev Hospital, Copenhagen, Denmark

JøRGEN G BERTHELSEN, MD, senior research fellow

NIELS E SKAKKEB®K, MD, DR MED, consultant andrologist (present appointment: professor of paediatrics, Children's Hospital, Fuglebakken, Copenhagen, Denmark)

Department of Oncology, Herlev Hospital, Copenhagen, Denmark HANS VON DER MAASE, MD, research fellow

Department of Surgery, Finsen Institute, Copenhagen, Denmark BENT L SØRENSEN, MD, DR MED, chief surgeon
University Department of Urology, Herlev Hospital, Copenhagen, Denmark
PETER MOGENSEN, MD, DR MED, senior registrar

second cancer may arise several years later. ${ }^{2} 3 \mathrm{~A}$ neoplasia may, however, be present as clinically undetectable carcinoma-insitu changes of the contralateral testis at the time of treatment of the first tumour. ${ }^{4-6}$ Consequently, we initiated screening for carcinoma-in-situ changes in the contralateral testis of patients with germinal testicular cancer in order to diagnose the condition at a preinvasive stage.

\section{Patients and methods}

During the period July 1972 to February 1982,250 biopsy specimens from the contralateral testis in patients with unilateral germinal testis cancer were analysed. During the first six years 13 biopsy specimens were received from one hospital whereas during the remaining years an increasing number of surgical departments participated in the study. During the last two years about $75 \%$ of new patients with cancer of the testis in the eastern half of Denmark were screened. No selection of patients was performed according to medical history or clinical features. The age and diagnosis of the patients are given in table I. All patients were investigated and treated according to the

TABLE I-Age, histological diagnosis, and clinical stage of testicular cancer in 250 patients

\begin{tabular}{|c|c|c|c|c|}
\hline \multirow[b]{2}{*}{ Diagnosis } & \multirow[b]{2}{*}{ Stage } & \multirow{2}{*}{$\begin{array}{c}\% \text { Of } \\
\text { patients }\end{array}$} & \multicolumn{2}{|c|}{ Age (years) } \\
\hline & & & Median & Range \\
\hline Seminoma & I & $\begin{array}{r}41 \cdot 6 \\
8 \cdot 8\end{array}$ & $\begin{array}{l}36 \cdot 3 \\
32 \cdot 9\end{array}$ & $\begin{array}{l}18-75 \\
17-68\end{array}$ \\
\hline Non-seminoma & $\begin{array}{l}\text { I } \\
\text { II } \\
\text { III }\end{array}$ & $\begin{array}{r}30 \cdot 8 \\
14 \cdot 0 \\
4 \cdot 8\end{array}$ & $\begin{array}{l}29 \cdot 7 \\
27 \cdot 2 \\
28 \cdot 3\end{array}$ & $\begin{array}{l}16-61 \\
17-59 \\
25-49\end{array}$ \\
\hline
\end{tabular}

Danish Testicular Carcinoma Study ${ }^{7}$ at the two oncological departments in Copenhagen.

Testicular biopsies of approximately $3 \times 3 \times 3 \mathrm{~mm}$ were excised from the contralateral testis either during orchidectomy or under local anaesthesia before further treatment. The biopsy specimens were fixed in Stieve's fixative ${ }^{8}$ or in Cleland's fixative,${ }^{9}$ embedded in paraplast, 
serially sectioned at 4- $\mu \mathrm{m}$ thickness, and stained with iron-haematoxylin and eosin. The sections were examined for the presence of carcinoma-in-situ changes ${ }^{4}$ (figs 1 and 2 ) by light microscopy at $\times 400-1000$ magnification. Patients with changes in the contralateral testis were clinically assessed every three months, which included orchidometer measurement of testicular size, and were advised to have a control biopsy performed every year.

Two non-parametric statistical tests were used: the $\chi^{2}$ test of the difference between proportions and the Kolmogorov-Smirnov test of the difference between cumulative probabilities.10

In this report the term "seminoma" indicates a tumour consisting solely of seminoma components while "non-seminoma" covers all other germ cell tumours ${ }^{11}$ whether a seminoma component is present or not.

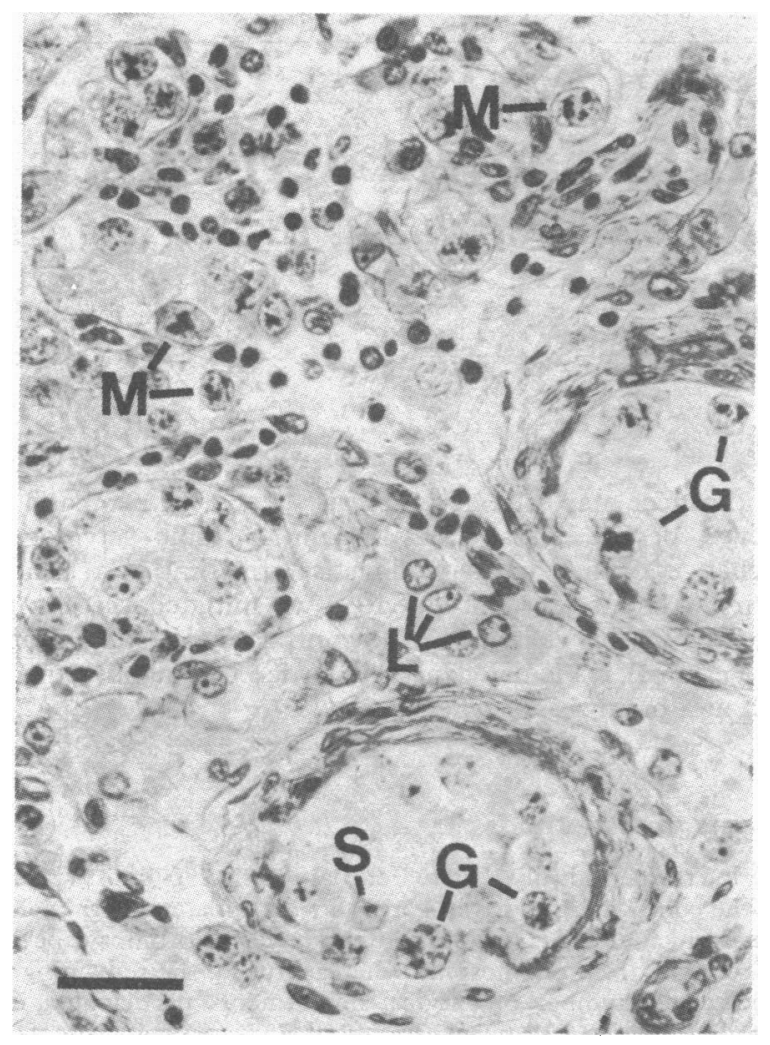

FIG 1-Histopathology of orchidectomy specimen (case 1) showing carcinoma in situ in two seminiferous tubules and invasion of malignant germ cells in the interstitial tissue. $\mathbf{G}=$ atypical germ cells (carcinoma-in-situ cells); $\mathbf{L}=\mathbf{L}$ eydig cells; $\mathbf{M}=$ malignant germ cells with similar morphology as $\mathbf{G}$; $\mathrm{S}=$ Sertoli cells of normal appearance. (Iron-haematoxylin and eosin, bar $=25 \mu \mathrm{m}$.)

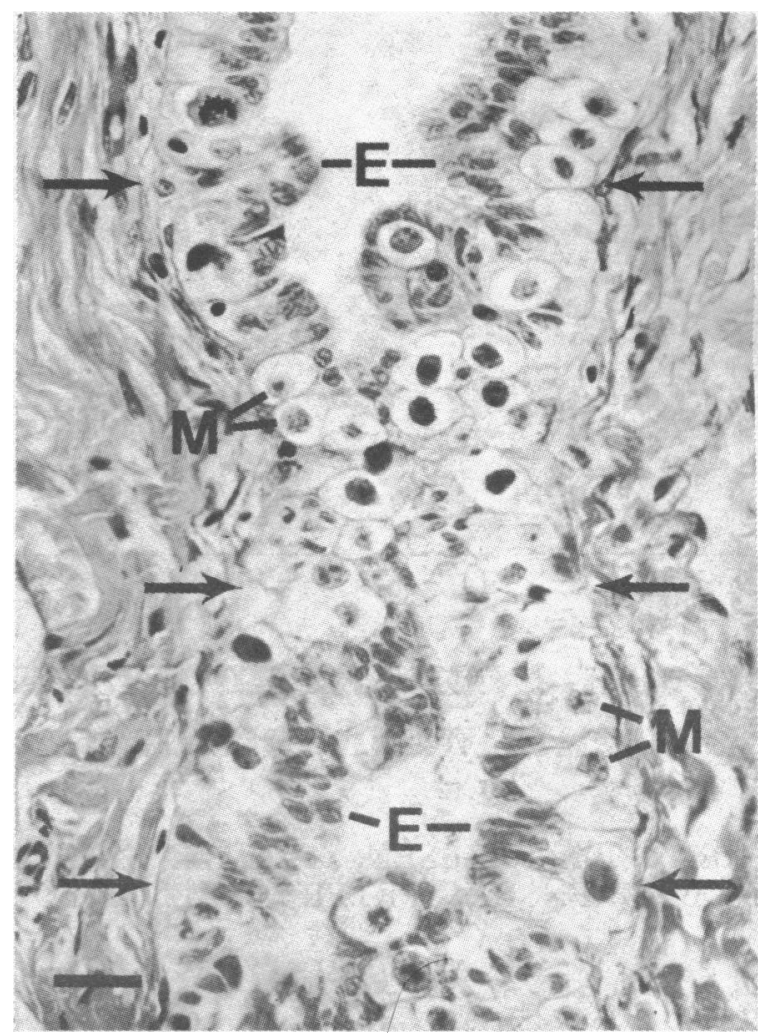

FIG 2-Histopathology of orchidectomy specimen (case 1) with rete testis epithelium showing invasion of malignant germ cells $(M)$ underneath the normal epithelial cells $(E)$. Arrows point to the limiting membrane. (Iron-haematoxylin and eosin, bar $=25 \mu \mathrm{m}$.)

\section{Results}

Thirteen of the 250 biopsies showed carcinoma-in-situ changes (incidence $5 \cdot 2 \% ; 95 \%$ confidence interval-2.8-8.8\%). Clinical datan on the 13 patients are given in table II and the histological data for thee primary as well as the follow-up biopsies in table III. Three of the $250^{\circ}$ specimens were uninterpretable because of faulty preparation.

Comparison of clinical data showed that the age distribution of 3 patients with carcinoma in situ with seminoma was similar to that of? the remaining patients with seminoma ( $>>0.05$, Kolmogorovo Smirnov test); there were too few patients with carcinoma in situ with non-seminoma for meaningful comparison. The proportion of seminomas in patients with carcinoma in situ was $77 \%$ compared with $49 \%$ in the remaining patients $\left(0.05<\mathrm{p}<0.1, \chi^{2}\right.$ test $)$ while the proportion of stage I and II + III tumours in patients with carcinoma in situwere similar to those in the remaining patients $\left(p>0.05, \chi^{2}\right.$ test).

TABLE II-Clinical data on the 13 patients with carcinoma in situ of the contralateral testis

\begin{tabular}{|c|c|c|c|c|c|c|}
\hline Case No & $\begin{array}{l}\text { Age (years) at } \\
\text { diagnosis }\end{array}$ & Histology, ${ }^{*}$ stage, and side of tumour & Treatment & $\begin{array}{l}\text { Cryptorchidism (side and } \\
\text { treatment) }\end{array}$ & $\begin{array}{l}\text { No of } \\
\text { children }\end{array}$ & $\begin{array}{l}\text { Volume o } \\
\text { testis (ml) }\end{array}$ \\
\hline $\begin{array}{l}1 \\
2 \\
3 \\
4 \\
5 \\
6 \\
7\end{array}$ & $\begin{array}{l}39 \cdot 5 \\
43 \cdot 2 \\
26 \cdot 3 \\
39 \cdot 1 \\
36 \cdot 7 \\
28 \cdot 2 \\
38 \cdot 7\end{array}$ & $\begin{array}{l}\text { Seminoma, I, right } \\
\text { Embryonal carcinoma and yolk sac, I, right } \\
\text { Seminoma, I, left } \\
\text { Seminoma, I, right } \\
\text { Seminoma, I, right } \\
\text { Seminoma, I, left } \\
\text { Seminoma, I, right }\end{array}$ & $\begin{array}{l}\text { Irradiation } \\
\text { Vinblastine, Bleomycin } \\
\text { Irradiation } \\
\text { Irradiation } \\
\text { Irradiation } \\
\text { Irradiation } \\
\text { Irradiation }\end{array}$ & $\begin{array}{l}\text { Right and left, untreated } \\
\text { Right, orchiopexia at } 11 \text { years } \\
\text { Right and left, spontaneous }\end{array}$ & $\begin{array}{l}0 \dagger \\
0 \ddagger \\
0 \ddagger \\
3 \\
1 \\
2 \\
3\end{array}$ & $\begin{array}{r}8 \\
5 \\
20 \\
15 \\
10 \\
6 \\
12\end{array}$ \\
\hline 8 & $33 \cdot 4$ & Malignant teratoma and seminoma, II, right & Irradiation, Vinblastine, Bleomycin, & & 2 & 12 \\
\hline $\begin{array}{r}9 \\
10\end{array}$ & $\begin{array}{l}34 \cdot 0 \\
32 \cdot 7\end{array}$ & $\begin{array}{l}\text { Seminoma, I, left } \\
\text { Seminoma, I, left }\end{array}$ & $\begin{array}{l}\text { Irradiation } \\
\text { Irradiation }\end{array}$ & $\begin{array}{l}\text { Left, orchiopexia at } 17 \text { years } \\
\text { One testicle, spont aneous descent }\end{array}$ & $\begin{array}{l}0 \ddagger \\
0 \ddagger \\
0 \ddagger\end{array}$ & $\begin{array}{l}20 \\
12\end{array}$ \\
\hline 11 & $30 \cdot 5$ & Yolk sac, II, left & $\begin{array}{l}\text { Vinblastine, Bleomycin, cis-dichloro- } \\
\text { diamineplatinum }\end{array}$ & & $0 \ddagger$ & 20 \\
\hline $12 \S$ & $\begin{array}{l}48 \cdot 4 \\
28 \cdot 7\end{array}$ & $\begin{array}{l}\text { Seminoma, I, right } \\
\text { Seminoma, II, left }\end{array}$ & $\begin{array}{l}\text { Irradiation } \\
\text { Irradiation }\end{array}$ & Left, orchiopexia at 5 years & $\begin{array}{l}3 \\
2\end{array}$ & $\begin{array}{r}6 \\
20\end{array}$ \\
\hline
\end{tabular}

" Histological classification according to World Health Organisation."

$\dagger$ Four years of infertility.

\pm No previous wish for conception.

$\$$ In addition to carcinoma in situ, malignant germ cells were suspected in the interstitial tissue but clarification depends on a new biopsy 
Forty-six per cent of the patients with carcinoma in situ had cryptorchidism of one or both testes (table II), which is significantly higher than the expected $10-12 \%$ among patients with testicular cancer in general $^{12}\left(p<0.0005, \chi^{2}\right.$ test). It is also noteworthy that $62 \%$ of the patients with carcinoma-in-situ changes had a subnormal testicular volume of the affected testis compared with an estimated incidence of $7 \%$ with small testes in the remaining patients $\left(p<0.0005, \chi^{2}\right.$ test).

The theoretical value of screening for carcinoma in situ in different subpopulations of the present series is estimated in table IV.

Histological analysis showed that tubules with spermatogenesis were present in $54 \%$ of the specimens from patients with carcinoma in situ compared with $97 \%$ of the specimens from the remaining patients ( $p<0.0005, \chi^{2}$ test). The proportion of tubules with spermatogenesis in testes with carcinoma-in-situ changes varied from $2 \%$ to $90 \%$. A detailed histological analysis of the first 200 biopsy specimens will be reported separately. ${ }^{13}$

Follow-up biopsies showed the pattern of changes in six patients (table III) but not in two who had been treated with chemotherapeutic cancer drugs. In two patients invasive tumour growth was found at 21 and 46 months (figs 1 and 2) after diagnosis of carcinoma patients die of the first cancer or some other unrelated cause. Thirdly, aggressive chemotherapy of the primary tumour may in some instances also cure the carcinoma in situ in the contralateral testis. Lastly, it is not known whether carcinoma-in-situ cells always progress to invasive cancer, although actual spontaneous disappearance of these cells in the testis has never been demonstrated. ${ }^{15}$

Reduced testicular volume was a striking clinical feature of the contralateral testes with carcinoma in situ, as it is in the testes with carcinoma in situ of infertile patients. ${ }^{5}$ Almost half the patients with carcinoma in situ had a history of unilateral or bilateral cryptorchidism. This is similar to the incidence of cryptorchidism in patients with bilateral germinal testicular cancer. ${ }^{2}{ }^{3}$ Although the pathophysiological relationship between carcinoma in situ, cryptorchidism, and small testes has not been determined, the increased incidence of these two clinical features in the group of patients with carcinoma in situ of the contralateral testis may be used in the future to identify subpopulations

TABLE III-Histology of contralateral testis in 13 patients with carcinoma in situ (CIS). (Figures in parentheses indicate number of months from diagnosis until last biopsy/orchidectomy)

\begin{tabular}{|c|c|c|c|c|}
\hline Case No & $\begin{array}{l}\text { Pretreatment biopsy findings } \\
\text { (histology of tubules) }\end{array}$ & $\begin{array}{l}\text { Post-treatment biopsy findings } \\
\text { (histology of tubules) }\end{array}$ & $\begin{array}{l}\text { No of post-treatment } \\
\text { biopsies }\end{array}$ & Orchidectomy specimen \\
\hline 1 & CIS, hyalinised & $\begin{array}{l}\text { CIS and undifferentiated germ } \\
\text { cell cancer }\end{array}$ & 1 & $\begin{array}{l}\text { CIS and undifferentiated } \\
\text { germ cell cancer }(46)\end{array}$ \\
\hline $\begin{array}{r}2 \\
3 \\
4 \\
5 \\
6 \\
7 \\
8 \\
9 \\
10 \\
11 \\
12 \\
13\end{array}$ & $\begin{array}{l}\text { CIS, Sertoli cell only hyalinised } \\
\text { CIS, spermatogenic cells } \\
\text { CIS, spermatogenic cells } \\
\text { CIS, spermatogenic cells } \\
\text { CIS, spermatogenic cells } \\
\text { CIS, Sertoli cell only } \\
\text { CIS, spermatogenic cells } \\
\text { CIS } \\
\text { CIS, hyalinised } \\
\text { CISS, spermatogenic cells } \\
\text { CIS, spermatogenic cells, hyalinised } \\
\text { CIS, hyalinised }\end{array}$ & $\begin{array}{l}\text { Sertoli cell only, hyalinised (37) } \\
\text { CIS, Sertoli cell only ( } 37) \\
\text { CIS, spermatogenic cells, Sertoli cell only (37) } \\
\text { CIS, spermatogenic arrest (24) } \\
\text { CIS (25) } \\
\text { CIS and seminoma } \\
\text { Spermatogenic cells, Sertoli cell only (13) } \\
\text { CIS, Sertoli cell only (7) } \\
\text { CIS, hyalinised (11) }\end{array}$ & $\begin{array}{l}3 \\
3 \\
3 \\
2 \\
1 \\
1 \\
1 \\
2 \\
1\end{array}$ & CIS and seminoma (21) \\
\hline
\end{tabular}

TABLE IV-Evaluation of hypothetical screening for carcinoma in situ (CIS) in different subpopulations of the present series of 250 patients

\begin{tabular}{|c|c|c|c|}
\hline Subpopulation & $\begin{array}{l}\text { Estimated } \\
\text { proportion }\left({ }_{0}^{\circ}\right) \\
\text { of total } \\
\text { population }\end{array}$ & $\begin{array}{l}\text { Incidence }\left({ }^{\circ}\right) \\
\text { of CIS* in } \\
\text { subpopulation } \\
\left(95^{*} \text { "confi- }\right. \\
\text { dence limit })\end{array}$ & $\begin{array}{l}\text { No }(\%) \text { of } \\
\text { patients with CIS } \\
\text { belonging to } \\
\text { subpopulation }\end{array}$ \\
\hline $\begin{array}{l}\text { With testicular volume } \leqslant 12 \mathrm{ml} \\
\text { With cryptorchidism } \\
\text { With no children } \\
\text { With seminoma }\end{array}$ & $\begin{array}{l}10 \\
12 \\
30 \\
50\end{array}$ & $\begin{aligned} 32 & (15-54) \\
20 & (8-39) \\
8 & (3-16) \\
8 & (4-14)\end{aligned}$ & $\begin{array}{r}8 / 13(62) \\
6 / 13(46) \\
6 / 13(46) \\
10 / 13(77)\end{array}$ \\
\hline or cryptorchidism or both & 19 & $23(12-38)$ & $11 / 13(85)$ \\
\hline
\end{tabular}

*In total group, $5 \cdot 2 \%(3-9)$.

in situ. The remaining three patients have been followed for three to eight months with no clinical evidence of tumour formation but they have not yet had a second biopsy performed.

Three biopsies were uninterpretable because of faulty preparation. In one of these patients a non-seminoma became clinically evident 30 months after irradiation and chemotherapy for a non-seminoma stage I tumour. None of the 234 patients without carcinoma-in-situ changes in the pretreatment biopsy specimen developed a tumour in the contralateral testis during the observation period.

\section{Discussion}

The incidence of carcinoma in situ in the contralateral testis was found to be twice as high as the presumed incidence of $1 \cdot 5-2 \cdot 8 \%$ of bilateral germinal testicular cancer. ${ }^{1-3} 14$ There may be several reasons for this. Firstly, the incidence of a second tumour arising in the contralateral testis is probably presently underestimated owing to a scarcity of prolonged and prospective investigations of unselected populations of patients with testicular cancer. Secondly, some testes with carcinoma-in-situ germ cells may not produce clinically detectable cancers before the of patients with testicular cancer who are at greater risk of carcinoma in situ in the remaining testis. In retrospect 11 out of 13 cases of carcinoma in situ in the present study would have been diagnosed if patients with a testis of $12 \mathrm{ml}$ or less or cryptorchidism or both had been examined. This would have reduced the screened population to about one-fifth of its present size. Our study did not determine whether other factors such as infertility or type of tumour were of use in defining populations to be screened.

There is no agreement on the management of carcinoma in situ in the remaining testis in patients with testicular cancer, ${ }^{16}$ mainly because the spontaneous course of the disease in these patients is unknown. The observation time of the present 13 patients with carcinoma in situ is still too short to elucidate this aspect, but at present two of the five patients who have been followed for more than three years have developed an invasive tumour.

In two of our patients chemotherapy may have modified the natural course of the carcinoma in situ, as follow-up biopsies failed to show changes. Continued observation will indicate whether this treatment can actually eradicate the premalignancy.

The degree of risk of not finding an existing carcinoma in situ at biopsy is unknown, but the changes are often found in most parts of the testis because they are multifocal and appear to spread along the affected tubules. Thus, the chance of detecting a carcinoma in situ by one biopsy has been found to be high even in cases where the actual volume of tubules with carcinoma in situ was less than $10 \%$ of the testicular volume. ${ }^{17}$ To date none of the patients without carcinoma in situ in the biopsy specimen has developed a tumour, but a much longer follow-up time is needed.

We thank the oncological departments at the Finsen Institute and Herlev Hospital for their helpful co-operation, the participating surgical departments, and the institutes of pathology at the Finsen 
Institute and Herlev Hospital for providing histological material. We gratefully acknowledge the technical assistance of Mrs Anneliese Persson. The study was supported by grants from the Danish Cancer Society and the Danish Medical Research Council.

\section{References}

${ }^{1}$ Hamilton JB, Gilbert JB. Studies in malignant tumors of the testis. IV Bilateral testicular cancer. Incidence, nature, and bearing upon management of the patient with a single testicular cancer. Cancer Res 1942;2: 125-9.

2 Pugh RCB, ed. Pathology of the testis. Oxford: Blackwell Scientific Publications, 1976.

${ }^{3}$ Sokal M, Peckham MJ, Hendry WF. Bilateral germ cell tumours of the testis. Br $\mathcal{F}$ Urol 1980;52:158-62.

4 Skakkebæk NE. Possible carcinoma-in-situ of the testis. Lancet 1972;ii: 516-7.

${ }^{5}$ Skakkebæk NE. Carcinoma in situ of the testis : frequency and relationship to invasive germ cell tumours in infertile men. Histopathology 1978;2: 157-70.

- Berthelsen JG, Skakkebæk NE, Mogensen P, Sørensen BL. Incidence of carcinoma in situ of germ cells in contralateral testis of men with testicular tumours. Br Med F 1979;ii:363-4.
7 Schultz HP, Arends J, Barlebo H, et al. The Danish testicular carcinoma study (DATECA). Dan Med Bull (in press).

${ }^{8}$ Lillie RD, Fullmer HM. Histopathologic technic and practical histochemistry. 4th ed. New York: McGraw-Hill, 1976.

${ }^{9}$ Rowley MJ, Heller CG. The testicular biopsy: surgical procedure, fixation, and staining technics. Fertil Steril 1966;17:177-86.

10 Conover WJ. Practical nonparametric statistics. 2nd ed. New York: John Wiley \& Sons, 1980.

11 Mostofi FK, Sobin LH. Histological typing of testis tumours. In: International histological classification of tumours, No 16. Geneva: World Health Organisation, 1977.

1. Batata MA, Chu FCH, Hilaris BS, Whitmore WF, Golbey RB. Testicular cancer in cryptorchids. Cancer $1982 ; 49: 1023-30$.

13 Berthelsen JG, Skakkebæk NE. Gonadal function in men with testis cancer. Fertil Steril (in press).

14 Blandy JP, Hope-Stone HF, Dayan AD. Tumours of the testicle. London: William Heinemann, 1970.

15 Skakkebæk NE, Berthelsen JG, Visfeldt J. Clinical aspects of testicular carcinoma-in-situ. Int $\mathcal{F}$ Androl 1981 ;suppl 4 : 153-62.

16 Anonymous. Testicular biopsy for early detection of testicular tumour. Br Med F 1980;i:426-7.

17 Berthelsen JG, Skakkebæk NE. Distribution of carcinoma-in-situ in testes from infertile men. Int $\mathcal{F}$ Androl 1981 ;suppl 4:172-84.

(Accepted 9 September 1982)

\title{
Erythropoietin and renal function in sickle-cell disease
}

\author{
A G MORGAN，CAROLYN A GRUBER，G R SERJEANT
}

\begin{abstract}
The relations between haemoglobin concentration, creatinine clearance, and the serum concentration of erythropoiesis-stimulating factor were assessed in 31 patients with homozygous sickle-cell disease. Haemoglobin concentrations fell significantly with decreasing creatinine clearance $(\mathbf{r}=0.58, \quad p<0.001)$ and were positively correlated with the concentration of erythropoiesis-stimulating factor $(r=0.65, p<0.001)$.

These observations suggest that erythropoietin concentration is the factor limiting production of red cells in sickle-cell disease with renal insufficiency and have implications for treatment.
\end{abstract}

\section{Introduction}

A previous study in patients with homozygous sickle-cell disease aged over $40^{1}$ indicated a strong positive correlation between haemoglobin concentration and creatinine clearance. Haemoglobin concentrations appeared to be adversely affected by fairly minor degrees of renal insufficiency, and we postulated that the bone marrow might be very sensitive to reduced erythropoietin concentrations. We investigated this possibility further by measuring serum concentrations of erythropoiesisstimulating factor, renal function, and haemoglobin concentrations in 31 adults with sickle-cell disease who were in a steady state (that is, free of acute complications of their disease) at the time of study.

University of the West Indies, Kingston 7, Jamaica

A G MORGAN, MD, MRCP, Wellcome senior lecturer, department of medicine (present address: medical unit, London Hospital Medical College, London E1 2AD)

G R SERJEANT, MD, FRCP, director, Medical Research Council laboratories

Upjohn Company, Kalamazoo, Michigan 49001, USA

CAROLYN A GRUBER, BA, research biologist, medical development and clinical laboratory research

\section{Patients and methods}

Patients with sickle-cell disease were chosen from those attending the sickle-cell clinic of the University Hospital of the West Indies, Jamaica, on the basis of their willingness to take part in the study. Each was admitted electively to hospital when free of acute complications of their disease. The diagnosis of sickle-cell disease was based on a single major haemoglobin band in the position of haemoglobin $S$ on cellulose acetate and agar-gel electrophoresis, compatible haemoglobin $\mathrm{A}_{2}$ concentrations, and family study when possible. No patient had received a transfusion within three months, and only two had been included in the earlier study. ${ }^{1}$

Creatinine clearance was determined from two consecutive $\overrightarrow{\bar{a}}$ 24-hour collections of urine and accompanying measurements of 3 serum creatinine concentration, and the result was expressed as the mean of the two estimations, corrected for surface area derived from $\overline{0}$ height and weight. Blood was drawn for measurement of serum urea concentration and standard haematological variables. Erythropoiesisstimulating factor was measured by a modification of the fetal mouse liver cell assay described by Wardle et al ${ }^{2}$ using sera stored without $\frac{\sigma}{\partial}$ preservative at $-70^{\circ} \mathrm{C}$ and thawed only once, just before the 3 estimation. After overnight incubation of cell cultures in the presence $\delta$ of either test serum or pooled normal serum supplemented with 3 sheep erythropoietin (stage III, Connaught Laboratories) activity of erythroid precursor cells was measured by the rate of incorporation of iron-59-labelled ferrous citrate into haem. Differences in uptake $N$ of ${ }^{59} \mathrm{Fe}$ because of differences in the iron content of sera were pre- $D$ vented by adding an excess of human transferrin. The mean normal values for this laboratory in 11 male and 10 female American subjects were $12 \cdot 8 \mathrm{U} / 1$ (range $4 \cdot 5-19 \cdot 8 \mathrm{U} / \mathrm{l}$ ) and $17 \cdot 2 \mathrm{U} / \mathrm{l}$ (range 10.8-27.0 U/1) respectively.

Student's $t$ test and linear regression were used for statistical $\sigma$ testing of results. As noted by others, ${ }^{3}$ concentrations of erythropoiesis- 0 stimulating factor had a skewed distribution, and logarithmic transformation was therefore performed before analysis.

\section{Results}

The study group consisted of 11 men and 20 women with a mean age of $37 \cdot 1$ years (range $15-66$ years). Five were already known to have renal failure (creatinine clearance $4-23 \mathrm{ml} / \mathrm{min} / 1.73 \mathrm{~m}^{2}$ ) ac- 8 companied by appreciable anaemia (haemoglobin concentration $3 \cdot 0-4 \cdot 9 \mathrm{~g} / \mathrm{dl}$ ). Two of these (women aged 64 and 65 years) had been 